\title{
Analisis pengaruh variasi bahan bakar terhadap uji efektivitas kompor biomassa
}

\section{Muhammad Afif Zakariya ${ }^{{ }^{\star}}$, Mochamad Arif Irfa'í' ${ }^{2}$, Mohammad Munib Rosadi}

\author{
Program Studi Teknik Mesin, Fakultas Teknik, Universitas Hasyim Asy'ari Tebuireng \\ Jombang ${ }^{1,2,3}$ \\ JI. Irian Jaya 55 Tebuireng Tromol Pos IX Jombang Jatim Telp. (0321) 861719 (Hunting), \\ 864206, 851396, 874685 Fax. 874684 \\ Corresponding author: afifzacky15@gmail.com
}

\begin{abstract}
The biomass stove is a simple stove option to save the use of petroleum and natural gas. This is because the fuel used in the biomass stove can be obtained continuously or it is called renewable energy. The renewable energy utilized in the biomass stove comes from biomass waste, namely coconut shell, corn cobs, and jackfruit wood which can be discovered easily in the surrounding environment. The problem in this research is the test of the effectiveness of the fuel on the duration of boiling water, while this study aims to determine the effectiveness of the biomass stove and the rate of energy increase from the fuel. This type of research is in the form of quantitative research with experimental methods. The results indicate that the biomass stove with corn cobs fuel was more effective because it only spent $0.28 \mathrm{~kg}$ to boil 1 liter of water. Processing data using the one-way ANOVA statistical test to produce the sig. value. 0.728, this shows that there is no significant difference in the effectiveness of the fuel variation.
\end{abstract}

Keywords: biomass stove, fuel, fuel effectiveness.

\section{Abstrak}

Kompor biomassa merupakan salah satu pilihan kompor sederhana untuk menghemat penggunaan minyak bumi maupun gas alam. Hal ini dikarenakan bahan bakar yang digunakan pada kompor biomassa dapat diperoleh secara terus menerus atau disebut energi terbarukan. Energi terbarukan yang digunakan pada kompor biomassa berasal dari limbah biomassa yaitu tempurung kelapa, tongkol jagung dan kayu Nangka yang dapat dijumpai dengan mudah di lingkungan sekitar. Permasalahan dalam penelitian ini adalah uji efektivitas bahan bakar terhadap lama waktu pendidihan air, sedangkan tujuan dalam penelitian ini adalah mengetahui efektivitas kompor biomassa dan laju pertambahan energi dari bahan bakar. Jenis penelitian yang digunakan berupa penelitian kuantitatif dengan metode eksperimental. Hasil penelitian menunjukkan bahwa kompor biomassa dengan bahan bakar tongkol jagung lebih efektif karena hanya menghabiskan $0,28 \mathrm{~kg}$ dalam mendidihkan 1 liter air. Pengolahan data menggunakan uji statistik ANOVA satu jalur dengan menghasilkan nilai sig. 0.728 , hal ini menunjukkan tidak terdapat perbedaan signifikan dari efektivitas variasi bahan bakar.

Kata kunci: kompor biomassa, bahan bakar, efektivitas bahan bakar

\section{Pendahuluan}

Indonesia merupakan negara yang mempunyai potensi energi terbarukan yang cukup besar. Hal ini dapat diketahui dari geografis Indonesia yang terletak diatas jalur gunung berapi, dan juga diapit oleh samudera Pasifik dan samudera Hindia. Adapun energi terbarukan yang cukup banyak dijumpai di lingkungan sekitar yaitu biomassa. Biomassa merupakan bahan yang diperoleh dari tumbuh- 
tumbuhan baik secara langsung maupun tidak dan dapat dimanfaatkan sebagai energi atau bahan dalam jumlah besar. Biomassa juga dikenal dengan bio resource atau sumber daya yang berasal dari hayati [8].

Penggunaan biomassa di lingkungan sekitar yaitu pada bahan bakar yang dapat menghasilkan energi panas yang ramah lingkungan, salah satunya yaitu penggunaan kompor biomassa. Kompor ini dianggap lebih efektif untuk menghemat pemakaian bahan bakar minyak bumi maupun gas alam, karena kompor biomassa menggunakan bahan bakar kayu, plastik, sampah, maupun daun tanaman yang telah mengering. Selain itu, kompor biomassa juga turut berperan dalam menjaga kebersihan lingkungan serta dapat mengurangi dampak pemanasan global.

Perancangan kompor biomassa di desain menggunakan material sederhana yang mudah di dapat dan mempunyai harga yang relatif murah. Hal ini dikarenakan kompor biomassa ditujukan pada masyarakat golongan menengah-kebawah, sehingga tidak membutuhkan biaya tambah dalam penggunaan yang berkelanjutan. Adapun pemilihan bahan bakar yang digunakan dalam pengujian kompor biomassa yaitu dengan memanfaatkan limbah yang kurang dimanfaatkan di lingkungan sekitar. Dalam penelitian ini, bahan bakar yang digunakan untuk pengujian kompor biomassa berupa tongkol jagung, tempurung kelapa dan limbah kayu nangka. Sehingga hasil analisis terhadap bahan bakar dalam pengujian nantinya akan dapat bermanfaat bagi lingkungan sekitar, dan dapat menerapkan kompor biomassa sebagai salah satu opsional pengunaan kompor sederhana dengan bahan bakar yang dapat diperbaharui dan mudah didapatkan, ramah lingkungan, serta memiliki nilai ekonomis yang relatif rendah.

\section{Tinjauan Pustaka}

Bahan bakar merupakan suatu bahan yang berfungsi dalam proses pembakaran.
Tujuan dari proses pembakaran bahan bakar yaitu untuk menghasilkan energi yang disebut energi panas, yang hasilnya dapat diubah menjadi energi lain, seperti energi penerangan, energi mekanis dan lainnya [7].

Bahan bakar berdasarkan sumbernya dapat dibagi menjadi 3, yaitu bahan bakar nabati, bahan bakar mineral, dan bahan bakar fosil. Bahan bakar nabati merupakan bahan bakar yang berasal dari tumbuhan. Adapun tumbuhan yang menjadi komposisi utama dalam pengolahan bahan bakar nabati berupa tumbuhan yang memiliki kandungan minyak. Bahan bakar mineral berasal dari tambang sehingga sering disebut dengan minyak bumi [6].

Bahan bakar fosil merupakan bahan bakar dengan sumber utama fosil, yaitu berasal dari organisme maupun tumbuhan yang telah lama mati yang mengendap di tanah. Perwujudan dari bahan bakar fosil sendiri berupa gas alam (gas), minyak bumi (cair), dan batubara (padat) [3]

Energi mempunyai arti sebagai kegiatan atau aktivitas. Menurut Robert L. Wolke energi yaitu suatu kegiatan untuk membuat sesuatu terjadi, dan masih banyak ungkapan mengenai definisi energi oleh para ahli terdahulu. Sehingga dapat disimpulkan bahwa pengertian energi adalah suatu usaha atau upaya agar segala hal yang ada di sekitar kita terjadi [5,9].

Sumber energi tak terbarukan atau disebut non-renewable energy yaitu sumber energi yang tidak bisa diisi ulang oleh alam dalam waktu yang singkat dan bukan merupakan suatu proses alam yang berkelanjutan. Sumber energi tak terbarukan berasal dari perut bumi yang berupa padat, cair, maupun gas.

Sumber energi terbarukan merupakan sumber energi yang proses pengisiannya berlangsung secara cepat dan diproses sendiri oleh alam. Potensi dari sumber energi terbarukan ini sangat besar, karena sumber energi ini dapat dengan cepat ditemukan dan diterapkan dilingkungan, seperti energi surya, energi angin, energi 
panas bumi, biomassa, bioetanol dan lainnya $[1,5]$.

Biomassa disebut sebagai energi terbarukan karena bahan dasar dari pemanfaatan biomassa berasal dari tumbuhan dan binatang. Sumber energi yang tersimpan dalam biomassa pada dasarnya berasal dari sumber energi matahari, yang kemudian diserap oleh tumbuhan melalui fotosintesis. Energi biomassa juga dapat dikonversi menjadi energi lain, seperti etanol, biogas dan biodiesel yang dapat digunakan untuk bahan bakar [2,8].

Definisi kompor menurut Kamus Besar Bahasa Indonesia adalah suatu alat perapian yang digunakan untuk memasak dengan bahan bakar menggunakan minyak tanah, gas maupun listrik. Bentuk kompor pertama kali berupa tungku atau biasa disebut tungku api. Tungku ini terbuat dari tanah liat yang dibentuk kotak persegi yang mengurung api, sehingga penggunaan tungku api tidak terlalu membahayakan penggunanya [4].

\section{Metode Penelitian}

Jenis penelitian yang penulis gunakan adalah penelitian kuantitatif dengan metode eksperimental dengan variabel bebasnya limbah tempurung kelapa, tongkol jagung, serta kayu nangka. Variabel terikatnya adalah efektivitas bahan bakar. Sedangkan variabel kontrolnya yaitu kompor biomassa, panci, massa bahan bakar, air volume 1 liter. Hasil yang diperoleh dari pengujian kemudian dianalisis dan mendapatkan kesimpulan. Berikut ini adalah flowchart penelitian yang dapat dilihat pada Gambar 1 sebagai berikut:

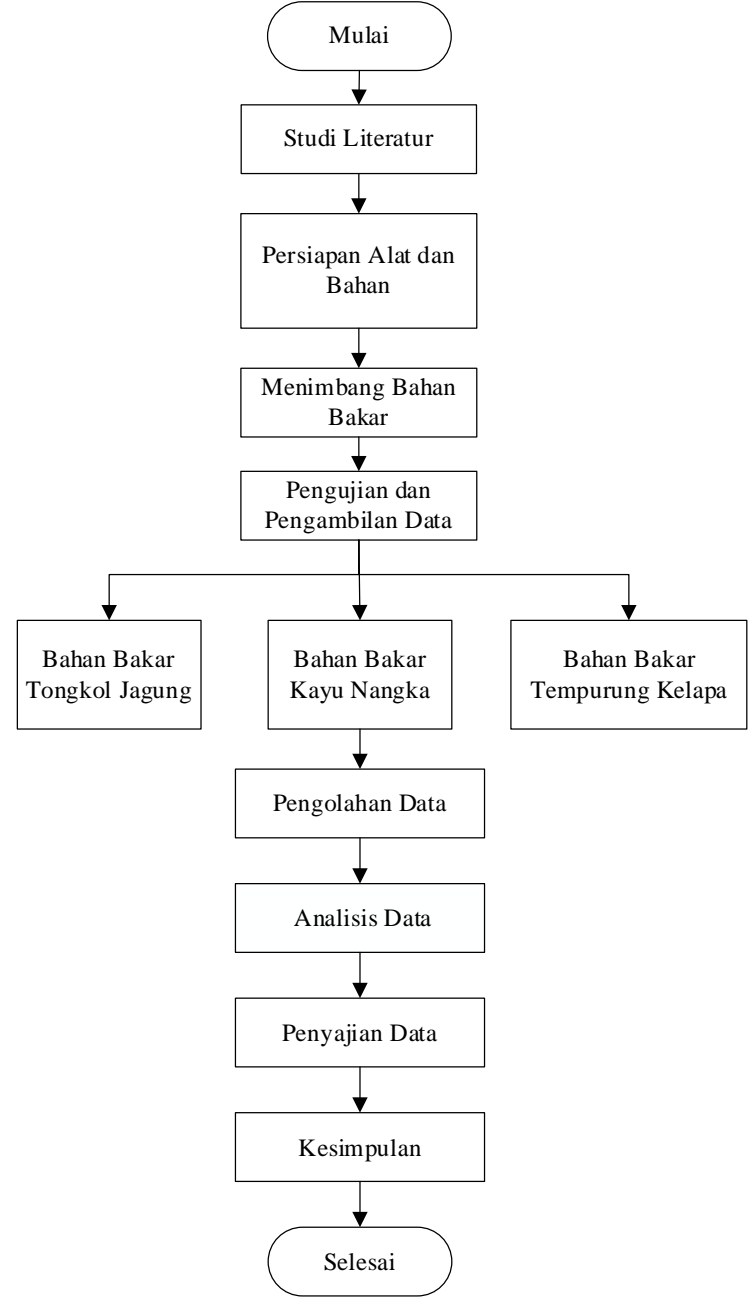

Gambar 1. Flowchart Penelitian.

Variabel yang digunakan dalam penelitian ini adalah sebagai berikut:

1. Variabel bebas

Variabel bebas merupakan variabel yang mempengaruhi dan yang menjadi sebab perubahannya variabel terikat. Pada penelitian ini varibel bebasnya adalah variasi bahan bakar yaitu tongkol jagung, tempurung kelapa dan kayu nangka.

2. Variabel terikat

Variabel terikat merupakan variabel yang dipengaruhi atau yang menjadi akibat karena adanya variabel bebas. Pada penelitian ini variabel terikatnya adalah efektivitas bahan bakar.

3. Variabel kontrol

Variabel kontrol merupakan variabel yang di kontrol dan dikendalikan. Pada penelitian ini variabel kontrolnya adalah kompor 
biomassa, panci, massa bahan bakar dan volume air 1 liter.

Kajian yang telah dipelajari oleh peneliti mengenai perancangan kompor biomassa hingga analisis dalam pengujian maupun pengolahan data nantinya akan menghasilkan data yang akurat dan valid dengan dibantu menggunakan software SPSS. Perancangan kompor biomassa terdiri dari beberapa tahap, tahap awal yaitu dengan menentukan desain alat dan juga persiapan alat serta bahan yang akan digunakan dalam penelitian. Setelah alat dan bahan telah dipersiapkan kemudian akan dirancang bagian kompor biomassa berupa tabung pelindung kompor biomassa dan tutup kompor yang berasal dari tabung bekas freon R22. Rancangan kompor biomassa selanjutnya yaitu membuat ruang bakar kompor biomassa dengan bahan dasar plat ketebalan $1 \mathrm{~mm}$. Tahap berikutnya yaitu dengan menggabungkan antar komponen kompor biomassa, yaitu pada komponen tutup kompor, tabung pelindung dan ruang bakar dirakit menjadi satu, sehingga didapat produk kompor biomassa dengan bahan dan alat yang sederhana dan mudah untuk dirancang.

Langkah yang diambil setelah produk kompor biomassa telah selesai dirancang adalah menguji kompor biomassa dengan cara mendidihkan air volume 1 liter yang dimasak dengan menggunakan bahan bakar limbah biomassa berupa tongkol jagung, tempurung kelapa, serta kayu nangka. Dalam pengujian kompor biomassa, hal yang menjadi acuan untuk mendapatkan data antara lain dengan menggunakan alat pengukur suhu termometer untuk mengukur suhu air dan stopwatch untuk mengukur waktu yang ditempuh dalam proses pendidihan 1 liter air. Setelah memperoleh hasil kemudian dilakukan pengolahan data, analisis data dan penyajian data yang kemudian data tersebut dapat disimpulkan sesuai dengan hasil yang di dapat saat penelitan.

Dalam memperoleh data yang diinginkan pada penelitian ini, peneliti melakukan pengujian dengan cara :
1. Mengukur suhu air pada panci

2. Mengukur waktu dalam proses pendidihan

Dalam penelitian ini analisis yang digunakan adalah analisis komparasi, yaitu dengan membandingkan antara bahan bakar tongkol jagung, tempurung kelapa dan kayu nangka terhadap efektivitas bahan bakar dari tiap bahan bakar.

\section{Hasil dan Pembahasan}

\section{Pengujian kompor biomassa}

Kompor biomassa yang telah selesai dirancang nantinya akan diuji berdasarkan fungsinya maupun diuji berdasarkan dari variasi bahan bakarnya. Pengujian berdasarkan fungsi merupakan pengujian terhadap kinerja kompor biomassa untuk mengetahui kompor tersebut bekerja dengan baik. Sedangkan pengujian kompor biomassa berdasarkan variasi bahan bakar adalah untuk mengetahui efektivitas dari masing-masing bahan bakar yang digunakan dalam penelitian ini.

Adapun langkah-langkah yang dilakukan pada proses pengujian kinerja kompor biomassa antara lain:

1. Menimbang bahan bakar yang akan digunakan dalam pengujian.

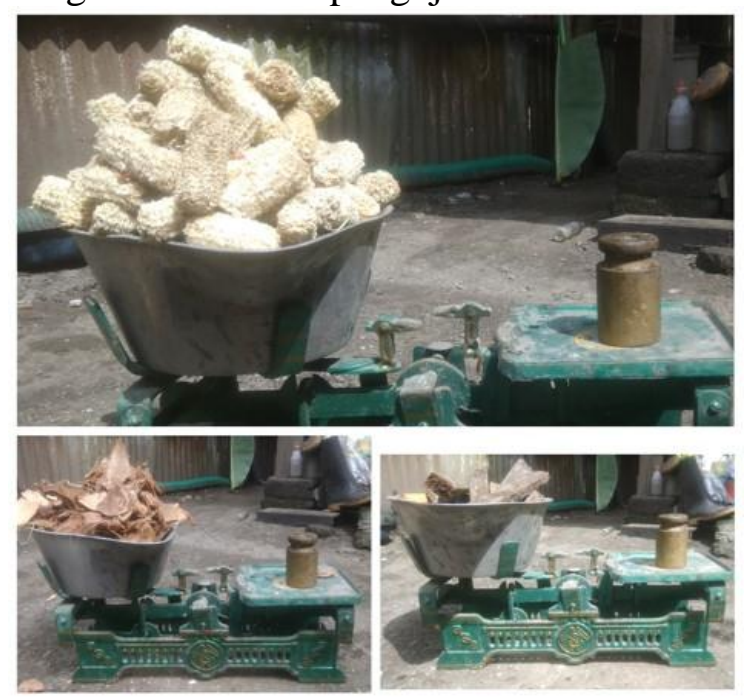

Gambar 2. Proses Menimbang Bahan Bakar

Memasukkan bahan bakar ke dalam ruang bakar melalui lubang bagian atas ruang bakar. 


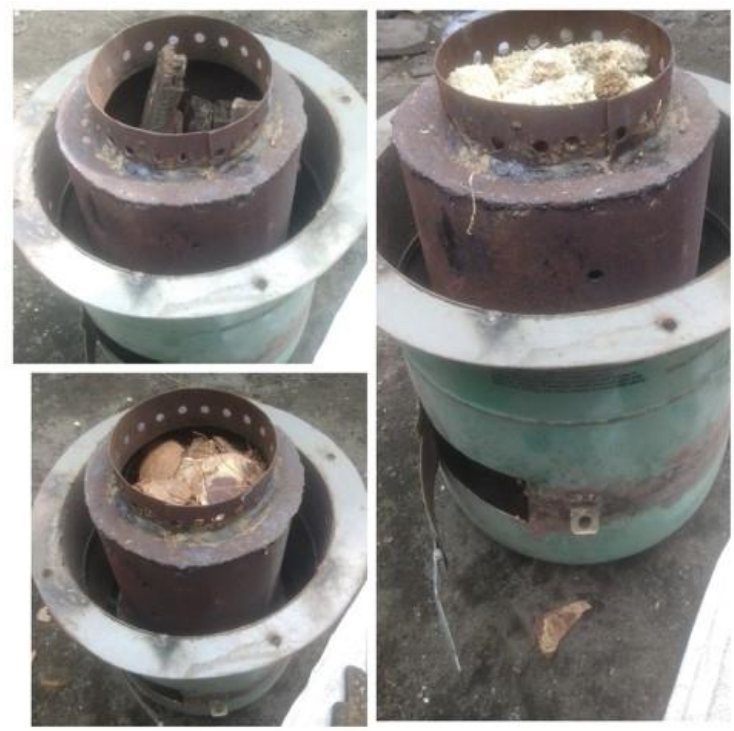

Gambar 3. Bahan bakar didalam Ruang Bakar

2. Tambahkan sedikit solar sebagai awal penyalaan api.

3. Nyalakan kompor biomassa dan tunggu sekitar 5 menit untuk mendapatkan nyala api yang merata.

4. Letakkan panci yang berisi air diatas kompor biomassa.

5. Tunggu hingga air mendidih.

6. Kemudian matikan kompor biomassa dengan cara menutup lubang angin pada semua sisi kompor. Sehingga api akan padam dengan sendirinya.

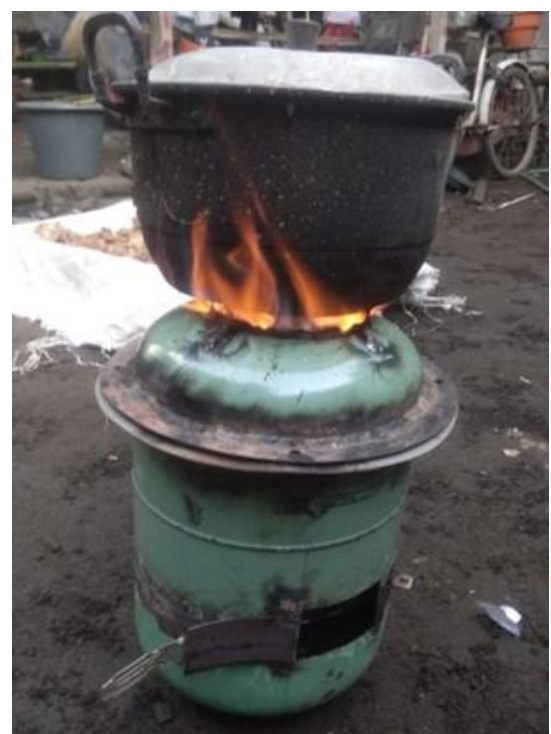

Gambar 4. Proses Pengujian

Berdasarkan tahapan pada proses pengujian kinerja kompor biomassa, jika telah didapatkan nyala api yang merata maka dapat disimpulkan bahwa kompor biomassa tersebut dapat bekerja dengan baik.

\section{Uji efektivitas bahan bakar}

Data hasil pengujian efektivitas kompor biomassa dengan variasi bahan bakar berasal dari pengujian kompor biomassa dengan memfokuskan pada penelitian mengenai berapa banyak penggunaan bahan bakar terhadap lama waktu pendidihan 1 liter air. Adapun hasil yang diperoleh dari masing-masing pengujian terhadap variasi bahan bakar dapat dilihat pada tabel berikut ini.

Tabel 1. Nilai Hasil Pengujian Efektivitas Bahan Bakar

\begin{tabular}{ccccc}
\hline Jenis & $\begin{array}{c}\text { Pengu } \\
\text { jian } \\
\text { Kahan } \\
\text { Bakar }\end{array}$ & $\begin{array}{c}\text { Bahan } \\
\text { Bakar } \\
\text { Akhir } \\
(\mathrm{Kg})\end{array}$ & $\begin{array}{c}\text { Penggun } \\
\text { aan } \\
\text { Bahan } \\
\text { Bakar } \\
(\mathrm{Kg})\end{array}$ & $\begin{array}{c}\text { Rata-rata } \\
\text { Pengguna } \\
\text { an Bahan } \\
\text { Bakar } \\
(\mathrm{Kg})\end{array}$ \\
\hline Tongkol & 1 & 0,7 & 0,3 & \\
Jagung & 2 & 0,75 & 0,25 & 0,28 \\
\hline Tempur & 1 & 0,7 & 0,3 & \\
ung & 2 & 0,3 & 0,7 & \\
Kelapa & 3 & 0,3 & 0,6 & 0,67 \\
\hline Kayu & 1 & 0,4 & 0,6 & \\
Nangka & 2 & 0,5 & 0,5 & 0,57 \\
\hline
\end{tabular}

Berdasarkan Tabel 1, diperoleh nilai efektivitas dari setiap bahan bakar yaitu tongkol jagung rata-rata menggunakan bahan bakar $0,28 \mathrm{~kg}$, untuk tempurung kelapa rata-rata penggunaan bahan bakar 0,67 kg, sedangkan untuk kayu nangka rata-rata penggunaan bahan bakar sebanyak $0,57 \mathrm{~kg}$. Dari penjelasan di atas maka dapat disimpulkan bahwa penggunaan bahan bakar tongkol jagung lebih efektif dari bahan bakar tempurung kelapa dan kayu nangka. Hal ini disebabkan oleh konsumsi bahan bakar tongkol jagung selama pengujian pendidihan air volume 1 liter lebih hemat dari bahan bakar lainnya, yaitu dengan rata-rata penggunaan bahan bakar adalah $0,28 \mathrm{~kg}$, untuk lebih jelasnya dalam membaca perbedaan konsumsi bahan bakar 
biomassa dapat dilihat pada grafik Gambar 2.

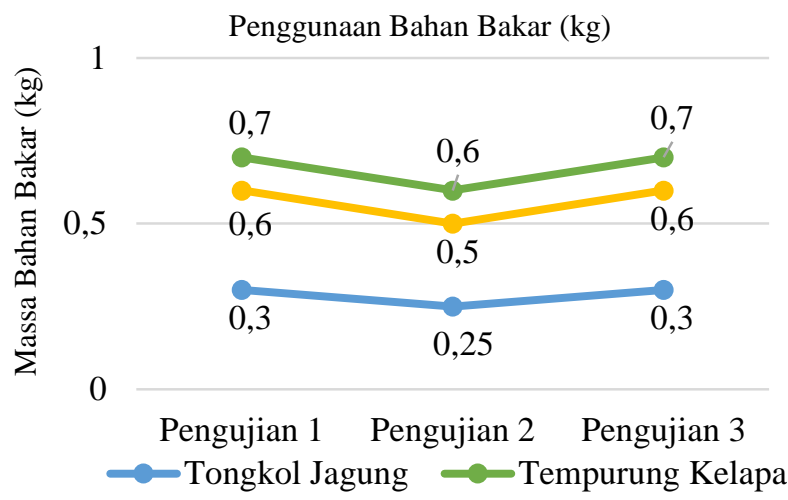

Gambar 2. Grafik Efektivitas Variasi Bahan Bakar Biomassa

Dari grafik Gambar 2 dapat dilihat perbedaan konsumsi bahan bakar pada masing - masing pengujian, sehingga nilai efektivitas bahan bakar didapat dari massa penggunaan bahan bakar yang paling hemat, yaitu pada bahan bakar tongkol jagung.

\section{Kesimpulan}

Berdasarkan pembahasan diatas, maka dapat ditarik kesimpulan yaitu pengujian kompor biomassa dengan bahan bakar tempurung kelapa yang digunakan untuk mendidihkan air dengan volume 1 liter adalah $0,67 \mathrm{~kg}$, bahan bakar tongkol jagung menggunakan $0,28 \mathrm{~kg}$ dan bahan bakar kayu nangka menggunakan $0,57 \mathrm{~kg}$. Sehingga dari ketiga variasi bahan bakar, nilai efektivitas yang didapat adalah dari bahan bakar tongkol jagung dengan penggunaan rata-rata $0,28 \mathrm{~kg}$.

\section{Referensi}

[1]. Anonymous. 2015. Energi Terbarukan. Retrieved From Majalah 1000 guru: http : // majalah1000guru.net/2015/01/energiterbarukan/, diakses pada 27 Januari 2020.

[2]. Anonymous. 2020. Asal Energi Biomassa. Retrieved From Amazine: https:// www. amazine. co/27020 / apa-itu-energi-biomassa-definisi-dan4-contohnya/, diakses pada 24 Januari 2020.

[3]. Contaned Energy Indonesia. 2010.

Buku Panduan Energi yang Terbarukan. Denmark: Internatinal Development Cooperation.

[4]. Kamus Besar Bahasa Indonesia. 2020. Kompor. Retrieved From kbbi: https://www.kbbi.web.id/ kompor, diakses pada 24 Januari 2020.

[5]. Kandi dan Winduono, Yamin. 2012. Energi dan Perubahannya. Bandung: Pusat Pengembangan dan Pemberdayaan Pendidik.

[6]. Prihajatno, Muji. 2009. Diktat Ilmu Bahan, Bahan Bakar, dan Pelumas. Jakarta.

[7]. Supraptono. 2004. Paparan Kuliah, Bahan Bakar dan Pelumas. Semarang: Universitas Negeri Semarang.

[8]. Yokoyama, Shinya dkk. 2008. Assian Biomass Handbook. Jepang: Asosiasi Biomassa Asia.

[9]. Zakky. 2020. Pengetian Energi. Retrieved From zonareferensi: https://www.zonareferensi.com/ pengertian-energi/, diakses pada 24 Januari 2020. 